\title{
Researchers in the panopticon? Geographies of research, fieldwork and authoritarianism
}

Article

Accepted Version

Menga, F. (2020) Researchers in the panopticon?

Geographies of research, fieldwork and authoritarianism. The Geographical Review, 110 (3). pp. 341-357. ISSN 1931-0846 doi: https://doi.org/10.1080/00167428.2019.1684197 Available at https://centaur.reading.ac.uk/87246/

It is advisable to refer to the publisher's version if you intend to cite from the work. See Guidance on citing.

To link to this article DOI: http://dx.doi.org/10.1080/00167428.2019.1684197

Publisher: Wiley

All outputs in CentAUR are protected by Intellectual Property Rights law, including copyright law. Copyright and IPR is retained by the creators or other copyright holders. Terms and conditions for use of this material are defined in the End User Agreement.

$\underline{\text { www.reading.ac.uk/centaur }}$ 
Central Archive at the University of Reading

Reading's research outputs online 


\title{
Researchers in the panopticon? Geographies of research, fieldwork and
} authoritarianism

\author{
Filippo Menga \\ Department of Geography and Environmental Science, University of Reading, United \\ Kingdom \\ Email:f.menga@reading.ac.uk
}

This is an Accepted Manuscript of an article published by Taylor and Francis in the Geographical Review [Article DOI 10.1080/00167428.2019.1684197].

\begin{abstract}
Building on an emerging scholarly literature that discusses methodological issues related to the safety of researchers, I explore the lived experiences of Western researchers who conducted fieldwork in authoritarian settings. Through an analysis of power as a relational phenomenon, the article examines the ways in which researchers are subject to diffuse topologies of power that can be deployed in various contexts and at various scales. Evidence suggests that as researchers immerse themselves into fieldwork, their everyday encounters with the authorities make them become progressively aware of their surroundings and of the fact that they might be being observed. Researchers thus discipline themselves and normalize a number of self-policing behaviours and practices that can significantly influence processes of knowledge production.
\end{abstract}

Keywords: authoritarianism, disciplinary power, fieldwork, panopticon, methodology.

\section{INTRODUCTION}

The death of Giulio Regeni, an Italian PhD candidate murdered in Egypt, and the arrest of Matthew Hedges, a British PhD candidate apprehended in the United Arab Emirates (UAE), are two of several recent events that remind us of the risks that researchers can encounter while conducting fieldwork in authoritarian settings. The importance of delineating best practices for fieldwork is reflected in an emerging scholarly literature that discusses methodological issues related to the safety of researchers, particularly while they are doing research in Asia and Africa. Several studies have been carried out in the fields of politics, international relations and anthropology, providing important insights into this research 
activity (Goode and Ahram 2016; Glasius et al. 2017; Peter and Strazzari 2017; Rivetti 2017; Bekmurzaev et al. 2018). In geography, research on fieldwork is also abundant. Questions related to fieldwork, the positionality of intellectuals, and the boundaries between being in and outside of the 'field' have been eloquently analysed by Katz (1994). Scholars have discussed procedures for carrying out fieldwork in transitional socialist countries (Scott et al. 2006), examined the complexities of positionality during fieldwork in feminist geography (Moss et al. 2002; Nagar and Geiger 2007, Caretta and Cheptum, 2017), while also acknowledging its importance (Hope 2009; Phillips and Johns 2012) and current relevance and potential as a research and data collection method [on this last aspect, refer to a special issue recently published in the Geographical Review (2019)]. Research has also illuminated the power dynamics and positionalities involved in the conduct of interviews on the field, looking for example at the role of gender (Chiswell and Wheeler, 2016) and of money and gift giving (Gillen, 2012) in articulating the relationship between researchers and respondents.

Fieldwork in authoritarian settings and its relevance for geographers is, likewise, receiving considerable attention (Sultana 2007; Bourke 2014), as also evidenced by a special issue on this theme published in Area (2013). Gentile's (2013) thorough discussion of the secret services in the post-communist space, highlighted the many security-related risks faced by researchers and their relative unpreparedness, compared to, for instance, journalists, to face them. Koch's work $(2013 ; 2016 ; 2017 ; 2018)$, in particular, shed light on the legitimation practices and power dynamics of authoritarian governments to discuss field methods and challenge the popular 'liberal/illiberal' and 'democratic/authoritarian' binaries that inform much social sciences research. Drawing on Harvey's (2000) argument that closure, intended as 'the making of something', is in itself an authoritarian act as it forecloses the possibility of materializing alternatives, Koch (2013: 390) foregrounds the term 'closed context' to denote "settings that are predominantly defined by the prevalence of such acts of closure - around the world". The value of such approach is that no place can be considered entirely authoritarian or entirely liberal, and defining it as such is of course a generalisation. Belcher and Martin (2013) illustrate this by showing the coexistence of - and sometimes improvisation behind - governmental technologies of openness and closure in what is generally considered a liberal state, the USA. The notion of closure is an important one: authoritarianism as a political technology of power is ephemeral, spatially diffuse and unfolds at multiple scales, as I will discuss in the following. 
In this article I build on the above literature by focusing on researchers and examining the governmentality of research on and in authoritarian (or closed) contexts when it is carried out by 'outsiders', i.e., by researchers that are not citizens of authoritarian countries. Geographers have raised awareness on the unequal relations between 'insiders' and 'outsiders' when doing fieldwork (Sidaway, 1992; Giwa, 2015), and discussed how a researcher's positionality influences his/her knowledge and understanding of the place they research (Mullings, 1999; Zhao, 2017), but the ways in which outsiders are subject to diffuse topologies of power that can be deployed in various contexts and at various scales deserves further attention. Through an analysis of power as a relational and diffuse phenomenon, I will disentangle the ways in which researchers are influenced by actual, or presumed, schemes of control put in place by governments and their security apparatuses.

This article is based on data sourced from 26 semi-structured interviews ${ }^{1}$ conducted between July 2017 and September 2018 with Western social scientists working in European higher education establishments and at various career stages, including: $\mathrm{PhD}$ students, postdoctoral researchers, lecturers, senior lecturers, readers and professors. The interviewees conducted fieldwork in Egypt, Ethiopia, Kazakhstan, Iraq, Israel, Laos, Libya, Palestine, Rwanda, Sudan, Turkey, Uganda, Uzbekistan, and Vietnam, which are all considered authoritarian or hybrid regimes by the 2017 Democracy Index (The Economist Intelligence Unit, 2018), and that respondents also identified as authoritarian based on their lived experiences. And yet, it is also necessary to note that there are different and more or less pervasive, visible, subtle or violent forms of authoritarian control, or in other words, certain settings are denoted by more acts of closure and the foreclosing of alternatives than others. Thus, conducting fieldwork in, for example, Sudan, entails a different set of conditions than, say, Israel, and this will inevitably lead to different lived experiences. Due to the sensitive nature of the topics discussed, interviewees have been anonymised and their identity replaced by their role and fieldwork location.

The rest of this article is structured as follows. In the next section I discuss authoritarianism and link it with Foucaldian theories of power, explaining why this is relevant to understand the challenges posed by carrying out fieldwork in authoritarian settings.

\footnotetext{
${ }^{1}$ In addition, I have had numerous informal conversations with academics and researchers about fieldwork experiences between May 2014 and October 2018.
} 
Following that, I document the processes through which researchers become both the target and the vehicle of diffuse topologies of power. I conclude by illustrating the findings of this paper and commenting on possible research directions on the geographies of fieldwork.

\section{AUTHORITARIANISM, GOVERNMENTALITY AND RELATIONAL POWER}

Rather than being merely bound to territory or delimited by a physical border, authoritarianism is a form of political and social control that operates in a seemingly borderless arena of political encounter and that, as such, can be easily manipulated or stretched by those in power (Menga, 2017). The immaterial pervasiveness of authoritarianism and the breadth of its reach have been further amplified by digital technologies, as evidenced by the Russian disinformation campaign targeting the 2016 US Presidential elections (Michaelsen and Glasius, 2018). In the current post-globalised digital age, the relationship between surveillance and authoritarianism is thus becoming a central theme around which we can develop our understanding of the changing multiscalar nature of the state (Wood, 2017).

Authoritarianism, as Isaacs and Frigerio (2019) observed, is also a system of governance that is well aware of its insecurity and of the precariousness of its authority and existence. As a consequence, authoritarianism prospers on paranoia and relies on strategies of social control and surveillance to ensure its survival. At its extremes, such a pursuit of total control generally relies on a highly centralised and repressive government that hyperregulates and bureaucratises the social, cultural and economic activities carried out by its citizens under the banners of state sovereignty (Hamzawy 2017; de Oliveira and Verhoeven 2018; Edle and Joshua 2018; Leenders and Kholoud 2018). The case of Turkmenistan, for instance, where a governmental permit or stamp is required to carry out all sorts of activities - such as playing live music, buying a carpet or importing flowers (in this case seven different permits are required, Alternativnie Novosti Turkmenistana 2018) - and where precautionary arrests of citizens stepping out of the line are frequent (Human Rights Watch 2018), is a fitting, even though extreme, example of this exasperated 'bureaucratic sovereignty' (see also Cummings and Hinnebusch 2011).

Exercising (and being subject to) sovereign rule is one of the ways in which the asymmetrical relation between the state and its citizens unfolds, whereby the state intervention is justified and driven by the need to maintain the security of the population, thus foreclosing alternative courses of action. This can be linked, as Collier (2009) eloquently 
explained, with the work of Foucault in Security, Territory and Population (2007), in which the French philosopher returned to his analysis of the state, following his earlier work on the “individual” (Foucault 2012). As Collier $(2009,89)$ notes, Foucault identified "patterns of correlation" among various techniques (or technologies) of power within a triangle of sovereignty, discipline and security (such as the security of populations from external threats through the central theme of biopolitics), which embeds a non-hierarchical and diffuse "topology of power" that can be deployed in various contexts and at various scales, ranging from the micro-politics of the body to the biopolitics of population.

For Collier (2009), governmentality emerges as a form of reasoning invented and deployed by specifically situated actors in particular moments in time, where correlated forms (or nodes) of power are deployed differently, thus acquiring more or less prominence. From this we can infer that power exists and functions at different and interrelated levels, or scales. On the one hand, disciplinary power operates with individuals, and "tries to rule a multiplicity of men to the extent that their multiplicity can and must be dissolved into individual bodies that can be kept under surveillance" (Foucault 2003, 242). On the other hand, the assertion and legitimacy of sovereignty (through regulations and legislations) and the maintenance of security, can be connected to the biopolitics of population, whereby biopower does not target the 'man-as-body' but rather the 'man-as living-being' and as multitude (Collier 2009) (Foucault (2003) uses the example of Nazism to illustrate the application of biopower to biologically control and regulate a population based on race). According to Foucault (1986: 240), "a right of sovereignty and a mechanism of discipline [...] define [...] the arena in which power is exercised", and their interscalar relationship is marked by their complementarity and interdependence.

Governmentality is thus reflected in practices, or techniques, of power, driven by specific needs and objectives. As Lemke (2001) observed, governmentality is the mentality of governing, or in other words, "the intellectual processing of the reality which political technologies can then tackle" (Lemke 2001, 191). These various techniques (or technologies) of power, can be interpreted as "calculated tactics that guide everyday citizen-subjects to act in accordance with societal norms" (Ettlinger 2011, 538). To explain and understand the pervasiveness of authoritarian surveillance, the notion of the panopticon becomes analytically salient. As Bentham devised it, the panopticon is an annular building with two key features: its centre has a prominent watchtower, and its perimeter is divided into cells. On the one 
hand, the watchtower, through a system of angles and backlighting, allows those who are inside to see into the cells without being in turn visible. On the other hand, the cells have windows that face both the outside of the panopticon and the watchtower. Those who are in these cells can see the watchtower but cannot know if someone is actually inside watching them. They feel constantly observed and, as a consequence, discipline themselves to comply with what they think are the expectations of the observer. Hence, in the eyes of Bentham, the panopticon provided an ideal and effective system of surveillance, based on the principle that power should be visible but also unverifiable (Foucault 2012). Coercion, as Mitchell (1991, 8) noted, is thus "replaced by "the partitioning of space, the isolation of individuals, and their systematic yet unseen surveillance". The panopticon is an instrument of disciplinary power that acts on individuals so that they will self-govern, something that emphasises the subtle way in which disciplinary power acts towards the subjectification of the individual, and that starkly contrasts with the direct governance and often brutal repression accompanying authoritarianism. Even though the panopticon provides us with only a partial account of a wider project on the 'policing of society' (Elden 2001) and of the workings of disciplinary power as they were developed by Foucault and subsequently picked up by several notable scholars (Mitchell 1991; Allen 2004; Ettlinger 2011; Elden 2016), it does serve as a powerful metaphor to understand the geographies of fieldwork and authoritarianism and the multiscalar relation between sovereign rule and disciplinary power.

The above discussion also opens the field to a multiscalar analysis, and indeed, as Ettlinger $(2011,538)$ thoroughly illustrated, "governmentality is geographic at its core". If we take, as she suggests, governmentality as epistemology - with epistemology referring to how we get to know things - then it appears that we have to focus on individuals if we want to know the workings of disciplinary power. Also, if we accept that power is everywhere because it comes from everywhere (Foucault 1984), we can overcome the binary view of power as a top-down process, to think instead of power as diffuse and as a relational and topological arrangement (Allen 2004; 2016; Collier 2009). Disciplinary power operates from within, "not at the level of an entire society but at the level of detail, and not by restricting individuals and their actions but by producing them" (Mitchell 1991, xi). If we are to understand how individuals - and in our specific case, researchers - become the target and vehicle of a diffuse power system and reproduce it within this relational arrangement, we then need to place our analytical focus on them and on their everyday practices. 
Everyday and at times mundane practices enacted by individuals (such as, in our case, getting on a taxi, requesting a letter of reference or applying for a research visa) can be directly related to authoritarian control exercised through sovereign rule and disciplinary power. These practices are part of a broader picture and they produce and reproduce societal norms, thus acquiring relevance in line with Foucault's (1980) ascending analysis. The way in which researchers interact with the authoritarian environment can tell a great deal about the norms and discourses that they absorb and reproduce: the everyday restrictions to their activities and the practices that they adopt to regulate themselves make them a subject of this environment and work towards the creation of a mentality. Mentalities produce practices and at the same time practices produce mentalities, they are mutually constituted.

\section{RESEARCHERS IN THE PANOPTICON? HOW PRACTICES CONSTITUTE A MENTALITY}

We can identify three main stages of fieldwork as a research activity: i) preparation; ii) time in the field; and iii) return home. During these stages researchers become both the target and the vehicle of sovereign and disciplinary power through mundane and everyday practices. While, as we shall see, many researchers felt constantly observed, rather than being subject to a panoptic surveillance it seems more appropriate to refer to a form of oligoptic control (Latour, 2005: 181), whereby only a few people or categories of people see or are seen, "but what they see, they see it well". This is because even in the most extreme forms of totalitarian rule, it is very hard to achieve total control, even though technology can facilitate this task (Wood, 2017).

Furthermore, and as it has been noted, the interviewees overall conducted fieldwork in 14 different countries, and therefore under 14 different forms of authoritarian control, and the following discussion needs to be read and understood with this in mind. All but 5 of the 26 respondents felt that they were being targeted by the authorities and as a result changed their behaviour. This applied to all of the early career researchers (ECRs), emphasising the importance of receiving proper training in advance of fieldwork to be better equipped to face real or presumed schemes of control. This is even more relevant if we consider that being an ECR often implies being a precarious worker, which might push researchers to take more risks during data collection to write a top publication. 


\section{Stage I: preparing for fieldwork}

Preparing for fieldwork is a time-consuming and ultimately bureaucracy-ridden, experience. While travelling to any foreign country involves a series of inevitable practical issues, these issues become more complex and at times frustrating when planning a research trip in an authoritarian country. In addition to the usual logistical arrangements such as booking a flight and accommodation, further ones stemming from bureaucratic sovereignty - such as being issued the proper entry visa or getting authorisation letters - can already pose a challenge.

The first steps, which are generally devoted to gathering information on the country and on the feasibility of fieldwork, introduce the researcher to some of the recurring elements of what can be termed a 'panoptic condition', namely the perception of risk and the notion of being controlled. Many of the interviewees explained that preliminary discussions with colleagues made them feel worried, triggering a sense of paranoia that accompanied them during fieldwork:

(Research Fellow, Uzbekistan) I met this researcher at a conference and I wish I didn't. He told me all these stories about being endlessly questioned at the airport and having his room searched by the authorities for apparently no reason. Most of the people I talked to had no particular issues, but this one...I just kept thinking about his words and this started to grow into me.

Sometimes this feeling of apprehension and the perception of risk was such that researchers changed their travel plans and choice of case studies:

(Research Fellow, Kazakhstan) I was working on this grant application and was developing what I felt was a good idea. I had chosen two case studies, and one of them was Tajikistan, as I knew this would make the project stronger and more likely to be funded. But some colleagues told me about being harassed while in Tajikistan, and then that researcher [Aleksandr Sodiqov] got arrested. Nobody in my department felt Tajikistan was a problem, but it was just because they knew nothing about it. I did my own ethics check and decided to replace it with Kazakhstan.

This resonates with the argument advanced by Ettlinger (2011) about the reproduction of societal norms through everyday practices such as conversations and observations. Researchers make sense of and eventually reproduce the information, norms, and discourses 
that have been passed on to them by other researchers or the media, and thus they become part of a macroscale societal picture. This process is further solidified by the ethical review that is generally required for research projects that entail fieldwork. Indeed, academics have to undergo rigorous ethics reviews before they can conduct research projects, but these procedures are usually designed to assure the preservation of the data collected and the protection of research participants (particularly those from potentially vulnerable groups). The physical, and to a larger extent, mental health of researchers is not contemplated. As a 4th year PhD student noted:

My ethics check was thorough about my research project and the data I was going to collect, but I did not receive any sort of support about myself and my wellbeing. Fieldwork policy is rubbish in my department. It is designed for the hard sciences, they [the ethics committee] have no idea of the stress involved in researching politically sensitive topics.

It is worth observing that these issues affect researchers at various career stages differently, and everyone copes in different ways with the pressure and the increased visibility involved with academic practice. While ethical checks tend to overlook issues related to the mental health of researchers, they do pay attention to country-specific security matters. Researchers, particularly early career, tend to gather this type of information from the website of the foreign ministry of their country of departure (such as the British 'Foreign Travel Advice', the Italian 'Viaggiare Sicuri', or the French 'Conseils aux Voyageurs'), but also through formal and informal discussions with colleagues:

(Research Associate, Ethiopia) Having to put that in writing for the ethical committee actually made me think that I was perhaps minimising the risks. I mean, colleagues at other universities warned me that working on political movements was a [sensitive] issue, and of course I knew that and I mentioned it in the form, but they [the ethics committee] were not too concerned about it based on my fieldwork experience in other countries ... which I guess was okay, but well...

Another key activity that researchers need to take on before departing for fieldwork is to apply for and obtain an appropriate entry visa, generally a business or a research one depending on the country (refer to Turner (2013) for a reflection on visas, red stamps and the 
politics of gatekeeping). While entering a country for research purposes with a tourist visa is reckless, dangerous, and in certain cases illegal, the majority of the interviewees have done this at least once in their career, and this is apparently common practice also for many of their colleagues. And yet, this is not due to sloppiness. It is not unusual that consulates deny visa applications, thus leaving tourist visas as the last resort to enter a country and carry on with a research project. This assertion of bureaucratic sovereignty is an act of closure that considerably limits the range of options available to outside researchers, while also overlapping with the workings of disciplinary power: a researcher conducting research on a tourist visa will indeed be conscious of this condition and more likely self-censor their work.

Documents that need to be produced for a research visa application generally include: a letter of invitation from a university based in the host country; a list of the people and places that the researcher intends to visit during their stay (with also the dates for each of the meetings in stricter cases like the one of Vietnam); an outline of the research project and of its main research questions. In this regard, the case of Sudan is particularly telling:

(Lecturer, Sudan) Following a first traumatic experience in which I was in the country with a tourist visa and got arrested for taking photos in public, I decided to enter the country through an official invitation from the university. In this case, the embassy insisted on seeing my previous academic papers, telling me that they were genuinely interested in my work, and upon arrival in the country I had to register at the immigration office and go through an intelligence screening.

Further fusing bureaucratic sovereignty with disciplinary power, researchers need to have their research plans vetted by the authorities before they can be issued an entry visa, and this reinforces in them the belief that their work in the country will be monitored. When they are going 'by the book', and as an additional precaution and a way to facilitate access to relevant people and places, scholars also try to get academic affiliations in their host country. And yet, also this activity can prove deleterious and further instil a sense of unease ahead of fieldwork:

(Lecturer, Ethiopia) The department was at first very welcoming and agreed to give me an affiliation as a visiting researcher. But then this started to take ages... after a few emails, they told me that they had read my papers and thought the topic was too sensitive. They started to make excuses and they eventually backed off. 
As the above discussion underlines, researchers can feel that the breadth and freedom of their research activities is limited already prior to departure. Not getting an appropriate entry visa or a letter of invitation can be a deterrent to carrying out fieldwork in a particular country. This serves as a preliminary skimming through which authoritarian places create a hostile environment for researchers, whereby direct bureaucratic sovereignty operates towards the subjectification of individuals. This is not necessarily part of a deliberate and malevolent plan against researchers, but rather the result of a series of systemic bureaucratic hurdles to otherwise uneventful mundane practices. Nevertheless, some individuals may feel that they are being directly targeted by the authorities, and thus start to discipline themselves.

\section{Stage II: in the field}

Upon arrival on the field, the panoptic condition has already been triggered in the researcher. Border controls at the airport - both when entering and leaving the country - are another powerful moment within the process that leads towards the subjectification of the individual. The airport, in general, rather than being the archetype of a relationally arid 'nonplace' (Augé 1995), is a place where uneven flows of people, capital and consumption are continuously negotiated (Lloyd 2002). As Adey (2004) noted, the airport intensifies the surveillance of people through various forms of monitoring and control that offer a 'blueprint for public space'. While Augé $(1995,103)$ maintained that airport passengers become anonymous subjects that experience "passive joys of identity-loss", this is not the case for scholars that are entering an authoritarian country, subjecting themselves to its sovereign rule and thus feeling anxious and self-conscious about their identity:

(Research Fellow, Israel) Before departure I always clear my Facebook and Twitter accounts, my laptop and my internet trail so that it is as neutral as possible, but I know that my papers are still out there and you just cannot delete everything. There was this time when I landed at Ben Gurion Airport and some men from intelligence pulled me aside. They googled my name and found out that I also did research on Israel...they kept me there for two hours asking me the same four or five questions, looked into my laptop and smartphone, and finally let me go.

In spite of the fact that this is likely to have been a random and routine control carried out to anyone visiting Israel and not specifically targeting scholars, it marked the researcher, as they 
felt that the gaze of the regime was close and inquisitive, and this left them with a feeling of unease for the remainder of their stay in the country. Likewise, several researchers, and particularly those working on politically sensitive issues, underlined a feeling of nervousness and sometimes fear when they were about to have their passports checked at the end of fieldwork:

(Research Associate, Uzbekistan) My research stay had been fine, even though less productive than what I had hoped. I did manage to get a couple of good interviews, no big deal but potentially [sensitive] stuff. I was tired and happy to be going back home. When I was in the queue for the passport control I started to have this stomach pain... what if they were waiting for me? I thought that maybe I went too far with my research... but I tried to look calm as I knew this was irrational, and indeed everything went fine.

Interaction with the authorities is inevitable for those travelling through airport security (and crossing borders in general) in and this is perhaps the reason why airports emerge as a particularly stressful place for researchers. Actual encounters with the regime and its sovereign rule can of course happen also outside of airports, even though these are less predictable and more unsettling. The in-depth interviews revealed that researchers often thought that they were being followed and observed in their daily activities and this happened mainly while they were travelling by taxi or sitting at restaurants and cafes. Gender does play a role in these settings (Sundberg, 2003; Momsen, 2006), and female respondents generally felt more unsafe and took more precautions in these situations than male respondents. The sight of police and (presumed) intelligence officers is a source of tension, but meetings with local journalists and politicians can also be alarming:

(Lecturer, Rwanda) The press is very constrained and some newspapers are harassed by the government. Some of the journalists I met showed me their scars, some of them were put in jail. I know that I was followed while meeting with a journalist, he made me notice that pointing at a man sitting in the cafe. This was my first experience of not knowing what was happening, and this was unsettling. There was an atmosphere of intense paranoia. 
This is an important point, as it introduces a central and yet subtle element in the subjectification of the individual. Being overtly questioned by the police (and thus subject to sovereign rule) is troubling, but even more so is the idea that this can happen, and this is grounded on the information (and sometimes rumours) that are passed on to researchers before and during their time in the field. "With the big brother inculcated in you", as a $\mathrm{PhD}$ student put it, "you are never fully relaxed or at ease during your daily routine and your research". As a consequence of this state of mind, researchers feel the need to police themselves to limit risks and avoid crossing what Glasius et al. $(2017,37-38)$ referred to as 'red lines', i.e., "topics or issues that are sensitive in the sense that investigating them is considered threatening or forbidden by the regime".

And yet, some of the interviewees had a different perception of the state and its officials, and even though they are a minority of the respondents, their experience is nevertheless significant. A PhD student working on Laos, for instance, felt that the government was observing their (and every other researcher's) moves, but this was not perceived as an intimidation, since they entered the country with the appropriate visa and held a letter of invitation from the Ministry of Foreign Affairs. Similarly, a reader who conducted fieldwork in Libya during the Gaddafi regime never had a concern about the government:

\section{I felt that the state was there to help, as I am afraid of anarchy. I don't work on politically sensitive issues, and this is possibly the reason why I never had any real issues. The secret services in Libya were particularly easy to be spotted, as they were wearing suits in the middle of the desert and would come talking to you about how good Gaddafi was. But they have never been a problem.}

Barring these exceptions, the above highlights some of the ways in which the researchers' perceptions of authoritarianism and their career survival strategies can influence and limit knowledge production processes. If a researcher is to cautiously navigate these red lines, some questions will necessarily have to be avoided, some places will not be visited, and some research avenues will not be explored, in line with the argument advanced by Turner (2013). "No, I do not ask some of the questions that I know I should be asking, I don't like this but I need to keep access to the country also in the future", commented a lecturer working on Ethiopia. 
(Research Fellow, Kazakhstan) Yes, I censor myself. I have depoliticised my research, both to protect myself and my informants. I felt the pervasiveness of the regime and their interest in knowing what I was doing ... There are many things that one can do without crossing the red lines, they are interesting and not risky, and I prefer going about my research this way.

Even though some of the interviewed researchers suffered from temporary arrests, explicit intimidations and even a beating while in the field, what seems to have had the greater impact on their mentalities and on the way in which they become vehicles of disciplinary power is the 'unknown', the sometimes paranoid belief that something bad will happen and wipe away their own work. Even when they are no longer in the field.

\section{Stage III: return home}

By the time they returned home, researchers have already become subjects and vehicles of disciplinary power and have normalized a series of self-policing behaviours and practices. They now need to compromise between what they want to include in their publications, and what they know they have to omit if they want to continue to conduct field research in a particular country. Furthermore, the fact that they are no longer in the field, does not necessarily imply that they are not being controlled. Two of the interviewees explained that their personal laptops got ratted ${ }^{\mathrm{i}}$ while they were at home visiting some government websites, and as a result they pay even more attention to the websites they visit and the keywords they enter in online searches. Issues arising from cyber security are clearly relevant to this discussion, and the potential implications of online spying on researchers are yet to be studied and understood. Yet, also more traditional forms of control can take place outside of the field. A particularly effective one, which was experienced at least once by many of the interviewed researchers, occurs at conferences:

(Research Fellow, Ethiopia) I was at a big conference on African studies and the ambassador approached me before my presentation. "I am looking forward to hearing what you have to say about our country”, he said, "as you know we are very concerned about this issue". I was stunned. I had no idea that he knew who I was and I wasn't expecting the government to be there. I slightly changed some of the points 
that I wanted to make in my talk and toned down my criticisms of the government to avoid a confrontation .

The presence of government officials at international conferences (particularly area-studies ones) extends the territoriality of authoritarian regimes, and with it the perceived reach of their gaze. Researchers are also aware that in the future they will probably want to go back to the country that they are studying, and they therefore keep being cautious about what they say and write. This has an impact on the content of their academic articles, but also on the outlets that they target for their public dissemination works. International Relations scholars, for example, will avoid popular magazines like Foreign Affairs or Foreign Policy in an attempt to elude authoritarian control and limit the visibility of their research. Respondents also highlighted a tension between the open-access mandates set by funding agencies, and the fact that making sensitive research available to anyone can sometimes be problematic:

(PhD Student, Palestine) There is at least one great paper that I could have written but that for the moment is still sitting in one of my brain folders, I would like only a few people to read it ... it will probably stay there for a while as I enjoy the country and there is still so much for me to do there.

Researchers working in authoritarian settings are thus permeated by disciplinary power, and this influences the professional as well as the mundane practices that they adopt in all the three main stages of fieldwork as a research activity, with a further impact on their future career choices. The vast majority of the interviewees explained that they consciously limit themselves and the extent of their research in order to avoid issues with the regime.

Difficulties in conducting fieldwork may sometimes lead researchers to shift their attention to new case studies, but most will continue to work on the same country taking the precautions discussed above.

\section{CONCLUSIONS}

In this paper I have examined the lived experiences of researchers who have conducted fieldwork in authoritarian settings. By doing this, I have engaged in a broader reflection on the ways in which power emerges as a relational and diffuse phenomenon. Evidence suggests that as researchers immerse themselves into fieldwork, their everyday encounters - either actual or imagined - with the authorities make them become 
progressively aware of their surroundings and of the fact that they might be being observed. Authoritarianism thrives on control, paranoia and uncertainty, on the normalisation of the assumption that anyone at any time can be questioned by the regime. As a result, researchers consciously discipline themselves and normalize a number of self-policing behaviours and practices that can significantly influence and limit processes of knowledge production. This happens within an increasingly metric-driven higher education sector that raises expectations about the work of researchers, and thus further exacerbates a feeling of stress and anxiety about the value and use of the data gathered during fieldwork.

The study has found that ECRs are particularly permeated by this diffuse power system. This suggests that higher education institutions should do more to train researchers and prepare them to face and overcome the main challenges posed by fieldwork in authoritarian settings. Even though ethics checks are time-consuming and are often perceived as a bureaucratic ordeal, they represent a crucial tool - together with tailored training activities - that universities can use to facilitate meaningful research in spite of the limitations and constraints discussed earlier. It is important to take all necessary measures to ensure the protection of research participants, but equal attention has to be placed on researchers and on their evolving professional and personal needs. To do so, and in line with the argument advanced by Sultana (2007), universities need to bridge the disconnect between their institutional procedures and the everyday, contextual, mundane, discipline-specific and relational nature of fieldwork. This becomes even more relevant in light of a research environment that has greatly enhanced (and valued) the visibility of researchers and of their work through the internet and social networks, but has not yet embodied these new structural developments in departmental research practices and regulations.

It also needs to be pointed out that 5 of the 26 respondents did not feel nor actually found themselves being surveilled, and therefore the above discussion does not sum up the experience of all researchers working in authoritarian contexts. Of further relevance, and unsurprisingly, scholars working on politically sensitive subjects generally tended to selfcensor themselves more than those working on more 'neutral' subjects and disciplines, such as paleoarchaeology or physical geography. Also, although this study focused on researchers, similar experiences might be had by other 'outsiders' working or visiting authoritarian settings, such as aid workers, journalists or tourists, and this raises questions about broader patterns of closure put in place by authoritarian countries. 
While the governance of the self can, on the one hand, allow individuals to distance themselves from a broader system of governance (Ettlinger 2011), on the other hand it can lure them into the system. Foucault's $(1980 ; 2006 ; 2012)$ insight into the diffusion of power resonates with Butler's $(2009,10)$ argument that "performativity does not just refer to explicit speech acts, but also to the reproduction of norms". Individuals can indeed absorb and reproduce societal norms and discourses, embed them into their practices and inculcate them into their mentalities. Researchers and fieldwork can exemplify this process, but this applies to all domains in which social relations and power dynamics are involved. And in all these domains there are, nonetheless, opportunities for resistance. As Leonardi (2013) pointed out, subjectification is not inevitable. Individuals can subtract themselves from some of the practices that lead to their submission to others through, for instance, new forms of sociality or redefinitions of their attributed identities. If we accept that the authoritarianism is grounded on uncertainty and disorientation, then emancipation from its control goes through information richness, peer mentoring and exchange, and proper institutional guidance. While fieldwork in authoritarian settings will always involve challenges, starting a conversation about these issues can help researchers prepare emotionally and strategically.

This is why I decided to write this paper and, by doing this, contribute to the growing research agenda on the geographies of fieldwork. In this effort, I have examined Western researchers' lived experiences of fieldwork in authoritarian settings, a research activity that speaks to some key issues in human geography such as place, mobility, power, perception of the other and scale. Future studies could build on the contributions of this work and expand its scope by examining broader trends in the geographies of research, with regard to what are the most studied countries by Western and non-Western researchers and for what reasons. This also calls for explorations of mechanisms related to biopower aimed at identifying patterns and to understand, for instance, if some countries are more successful than others in keeping researchers at bay. In relation to this, a deeper examination of how researcher's' trajectories shift depending on their positionality and lived experiences is also something that deserves to be investigated. Finally, to circumvent the Western positionality that marks this article, the everyday and mundane experiences of non-Western researchers working, for example, in Europe, also needs to be studied, particularly in relation to different perceptions of ethical values and of what is and what is not 'authoritarian'. This binary (Western/nonWestern) ontology continues to reproduce my own positionality and as such is partial and 
incomplete. I therefore hope that geographers specifically, and social scientists more in general, will engage with my proposals and help us find a way forward to better understand the environment we work in.

\section{REFERENCES}

Adey, P. 2004. Surveillance at the airport: surveilling mobility/mobilising surveillance. Environment and Planning A36 (8): 1365-1380.

Allen, J. 2004. The whereabouts of power: politics, government and space. Geografiska Annaler: Series B, Human Geography86 (1): 19-32.

Allen, J. 2016. Topologies of power: beyond territory and networks. Abingdon: Routledge.

Alternativnie Novosti Turkmenistana. 2018. Bureaucracy obstructs Turkmenistan's flower imports, 25 April. [https://habartm.org/archives/8976].

Area. 2013. Special section: Field methods in closed contexts. 45(3)

Augé, M. 1995 Non-lieux. London: Verso.

Bekmurzaev, N., P. Lottholz, and J. Meyer. 2018. Navigating the safety implications of doing research and being researched in Kyrgyzstan: cooperation, networks and framing. Central Asian Survey37 (1): 100-118.

Belcher, O. and L. L. Martin. 2013. Ethnographies of closed doors: conceptualising openness and closure in US immigration and military institutions. Area45 (4): 403-10.

Bourke, B. 2014. Positionality: Reflecting on the research process. The Qualitative Report19 (33): 1-9.

Butler, J. 2009. Performatividad, precariedad y políticas sexuales. AIBR: Revista de Antropología Iberoamericana4 (3): 321-336.

Caretta, M.A., and Cheptum, F.J. 2017. Leaving the field:(de-) linked lives of the researcher and research assistant. Area49(4): 415-420.

Chiswell, H.M. and Wheeler, R., 2016. 'As long as you're easy on the eye': reflecting on issues of positionality and researcher safety during farmer interviews. Area48(2): 229-235.

Collier, S. J. 2009. Topologies of power: Foucault's analysis of political government beyond 'governmentality'. Theory, Culture \& Society26 (6): 78-108.

Cummings, S., and R. Hinnebusch, eds. 2011. Sovereignty After Empire: Comparing the Middle East and Central Asia: Comparing the Middle East and Central Asia. Edinburgh: Edinburgh University Press. 
de Oliveira, R. S., and H. Verhoeven. 2018. Taming Intervention: Sovereignty, Statehood and Political Order in Africa. Survival60 (2): 7-32.

Edel, M., and M. Josua. 2018. How authoritarian rulers seek to legitimize repression: framing mass killings in Egypt and Uzbekistan. Democratization25 (5): 882-900.

Elden, S. 2002. Mapping the present: Heidegger, Foucault and the project of a spatial history. London: Continuum.

Elden, S. 2016. Space, knowledge and power: Foucault and geography. London: Routledge.

Ettlinger, N. 2011. Governmentality as epistemology. Annals of the Association of American Geographers101 (3): 537-560.

Foucault, M., and F. Ewald. 2003. Society Must Be Defended: Lectures at the Collège de France, 1975-1976. Vol. 1. London: Macmillan.

Foucault, M. 1980. Power/knowledge: Selected interviews and other writings, 19721977. London: Pantheon.

Foucault, M. 1984. The history of sexuality: An introduction, volume I. Trans. Robert Hurley. New York: Vintage.

Foucault, M. 1986. Disciplinary power and subjection. In Power, edited by S. Lukes, 232-242. Oxford: Blackwell.

Foucault, M. 2006. Psychiatric power: Lectures at the college de france, 1973-1974. Vol. 1. New York: Macmillan.

Foucault, M. 2007. Security, territory, population: lectures at the Collège de France, 1977-78. New York: Springer.

Foucault, M. 2012. Discipline and punish: The birth of the prison. New York: Vintage.

Gentile, M. 2013. Meeting the 'organs': the tacit dilemma of field research in authoritarian states. Area 45(4): 426-432.

Geographical Review. 2019. Special Issue: Fieldwork in Geography. (forthcoming, early view).

Gill, R. 2016. Breaking the silence: The hidden injuries of neo-liberal academia. Feministische Studien34 (1): 39-55.

Gillen, J. 2012. Investing in the field: Positionalities in money and gift exchange in Vietnam. Geoforum43(6):1163-1170.

Giwa, A. 2015. Insider/outsider issues for development researchers from the Global South. Geography Compass9(6):.316-326. 
Glasius, M., M. De Lange, J. Bartman, E. Dalmasso, A. Lv, A. Del Sordi, M. Michaelsen, and K. Ruijgrok. 2017. Research, ethics and risk in the authoritarian field. New York: Springer.

Goode, J. P., and A. I. Ahram. 2016. Special Issue Editors' Introduction: Observing Autocracies from the Ground Floor. Social Science Quarterly97 (4): 823-833.

Hamzawy, A. 2017. Legislating Authoritarianism: Egypt's New Era of Repression. Carnegie Endowment for International Peace.

Harvey, D. 2000. Spaces of hope. Edinburgh: Edinburgh University Press.

Hope, M. 2009. The importance of direct experience: A philosophical defence of fieldwork in human geography. Journal of Geography in Higher Education33 (2): 169-182.

Human Rights Watch. 2018. Turkmenistan Events of 2017.

[https://www.hrw.org/world-report/2018/country-chapters/Turkmenistan].

Isaacs, R., and A. Frigerio, eds. 2019. Theorizing Central Asian Politics: The State, Ideology and Power. London: Palgrave.

Katz, C. 1994. Playing the field: questions of fieldwork in geography. The professional geographer46 (1): 67-72.

Koch, N. 2013. Introduction-Field methods in 'closed contexts': undertaking research in authoritarian states and places. Area45 (4): 390-395.

Koch, N. 2016 We entrepreneurial academics: governing globalized higher education in 'illiberal'states. Territory, Politics, Governance4 (4): 438-452.

Koch, N. 2017. Orientalizing authoritarianism: Narrating US exceptionalism in popular reactions to the Trump election and presidency. Political Geography57: 145-147.

Koch, N. 2018. The geopolitics of spectacle: Space, synecdoche, and the new capitals of Asia. Cornell University Press.

Latour, B. 2005. Reassembling the Social: An Introduction to Actor-Network-Theory. Oxford: Oxford University Press.

Leenders, R., and K. Mansour. 2018. Humanitarianism, State Sovereignty, and Authoritarian Regime Maintenance in the Syrian War. Political Science Quarterly133 (2): 225-257.

Lemke, T. 2001. The birth of bio-politics': Michel Foucault's lecture at the Collège de France on neo-liberal governmentality. Economy and society30 (2): 190-207.

Leonardi, .E. 2013 Foucault in the Susa Valley: The No TAV Movement and Struggles for Subjectification. Capitalism Nature Socialism24 (2): 27-40. 
Lloyd, J. 2018. Departing sovereignty. Borderlands e-journal1 (2).

[http://www.borderlands.net.au/vol1no2_2002/lloyd_departing.html].

Menga, F. 2017. Hydropolis: Reinterpreting the polis in water politics. Political Geography60: 100-109.

Michaelsen, M., and Glasius, M. 2018. Authoritarian Practices in the Digital AgeIntroduction. International Journal of Communication12: 3788-3794.Mitchell, T. 1991. Colonising Egypt: With a new preface. Berkeley: University of California Press.

Momsen, J. H. 2006. Women, men and fieldwork: Gender relations and power structures. In Doing development research, edited by V Desai and R. Potter, 44-51. London: SAGE.

Moss, P., K. Falconer Al-Hindi, and H. Kawabata. 2002. Feminist geography in practice: Research and methods. London: Wiley-Blackwell.

Mullings, B. 1999. Insider or outsider, both or neither: Some dilemmas of interviewing in a crosscultural setting. Geoforum(30): 337-350.

Wood, D.M. 2017. The Global Turn to Authoritarianism and After. Surveillance \& Society $15(3 / 4)$ 357-370.

Nagar, R., and S. Geiger. 2007. Reflexivity, positionality and identity in feminist fieldwork revisited. In Politics and practice in economic geography, ed A. Tickell. E. Sheppard, J. Peck and T.J. Barnes , 267-278. London: Sage.

Peter, M., and F. Strazzari. 2017. Securitisation of research: fieldwork under new restrictions in Darfur and Mali. Third World Quarterly38 (7): 1531-1550.

Phillips, R., and J. Johns. 2012. Fieldwork for human geography. London: Sage.

Rivetti, P. 2017. Methodology Matters in Iran. Anthropology of the Middle East 12 (1): 71-82.

Scott, S., F. Miller, and K. Lloyd. 2006 Doing fieldwork in development geography: research culture and research spaces in Vietnam. Geographical Research44 (1): 28-40.

Sidaway, J. D. 1992. In Other Worlds: On the Politics of Research by 'First World' Geographers in the 'Third World'. Area(24): 403-408.

Sultana, F. 2007. Reflexivity, positionality and participatory ethics: Negotiating fieldwork dilemmas in international research. ACME: An international E-journal for Critical Geographies6 (3): 374-385.

Sundberg, J. 2003. Masculinist epistemologies and the politics of fieldwork in Latin Americanist geography. The Professional Geographer55(2): 180-190.

Turner, S. 2013. Red stamps and green tea. Area45(4): 396-402. 
The Economist Intelligence Unit. "Free speech under attack." A report by The Economist Intelligence Unit. 2018. The Economist, London.

Zhao, Y. 2017. Doing fieldwork the Chinese way: a returning researcher's insider/outsider status in her home town. Area49(2): 185-191.

\section{ACKNOWLEDGMENTS}

I am grateful to the editor and the three anonymous referees for their constructive and insightful comments. I also wish to thank Sophie Bowlby, Fiona McConnell and Annalisa Addis for their comments on earlier versions of the paper, and Natalie Koch for discussing this idea at its primordial stages. This paper should have been enriched by a drawing of the panopticon by Giaime Loi, a wonderful artist and friend who helped me make my writings a bit more humane, and who is no longer with us. Gimbo, ti ho voluto molto bene.

\footnotetext{
${ }^{\mathrm{i}}$ A computer gets ratted when a Remote Access Trojan (RAT) is installed in it, allowing a third user to, for instance, open its folders and delete or access its files.
} 